\title{
Small States in the United Nations Security Council: Legal and Conceptual Aspects versus Practical Perspective
}

\author{
Dr. sc. pol. Gunda Reire \\ Center for International Studies, Latvia \\ gunda.reire@gmail.com
}

\begin{abstract}
The article focuses on the prospects for work conducted by small states in the United Nations Security Council (UNSC) and examines two aspects which frame the work of small states in the UNSC - the legal aspect (institutional and procedural) and the conceptual aspect (the concept of small states), comparing them with the work and achievements of small states in praxis.

The aim of the article is to provide qualitative and comparative analysis of small states' work in the UNSC, to outline legal and political interpretation of their activities and to compare legal and conceptual framework with the practical perspective. The research is designed to be relevant for Latvia in the context of its candidature for a non-permanent seat of the UNSC at the elections in 2025, and it analyses cases of Lithuania's and Estonia's membership.

The author of the article argues that despite the minimal role provided for the small states in the UNSC by international law and the theoretical concept, cases of Lithuania and Estonia show that the practical perspective proves a much higher capability, influence and ability of small states to profile themselves actively within the global agenda while at the same time remaining in the aforementioned legal and conceptual boundaries. This can happen under circumstances where there are minor systemic challengers, lack of triggers for security of small states, and overlapping of the international security agenda and their field of expertise.
\end{abstract}

Keywords: United Nations, Security Council, small states, the Baltic States.

\section{Introduction}

Although non-permanent membership in the United Nations Security Council (UNSC) is not comparable with permanent membership in terms of the time period provided for the work, or in terms of power and influence, it is nonetheless widely acknowledged 
Gunda Reire. Small States in the United Nations Security Council:

Legal and Conceptual Aspects versus Practical Perspective

that being a non-permanent member of the UNSC improves a member state's international prestige and indicates its commitment to multilateralism and UN values. One third of the UN member states, Latvia among them, has never been a part of the UNSC. Latvia will be running for the non-permanent seat of the UNSC at the election in 2025 for the term 2026-2027; therefore, analysis of small states' limitations and opportunities in this international institution not only enrich academic debate about small states' role in global international affairs but is relevant as well for Latvia on a practical foreign policy level.

In contemporary international relations, small states are considered important actors because of the emphasis on the concept of multilateralism, the rise of the role of international institutions and the significant number of small states in the world, which makes them a force to be reckoned with when acting together.

The aim of the article is to provide analysis of prospects for active, effective, and visible work conducted by small states in the UNSC, to outline a legal and political interpretation of their possible and actual activities and to compare the legal and conceptual framework with the practical perspective.

Small states' theoretical concept emphasises that analysis of common behaviour patterns must be carried out by considering not only their physical and quantitative indicators, but also the common historical context and the geopolitical challenges they share. The research is designed to be relevant for Latvia in the context of its candidature for a non-permanent seat of the UNSC at the elections in 2025. Therefore, the article analyses two case studies UNSC memberships of Latvia's neighbouring countries Lithuania (for the UNSC term 2014-2015) and Estonia (for the UNSC term 2020-2021). Such a choice underlines shared features of small states and allows for drawing conclusions which are relevant for Latvia.

This article is structured in three parts which deal with conceptual aspects of small states role in international relations, the legal aspects of small states' membership in the UNSC, and the practical perspective of their work in the UNSC.

This article, by conducting qualitative, comparative, and legal analysis, shows, that the theoretical prospects for small states of capability, influence, and effective and visible work within the UNSC can be considered as minor because of the intersection of legal (institutional and procedural) and conceptual (the concept of small states) aspects. The legal aspect of the UNSC work is determined by the UN Charter and other UN documents, but the conceptual aspect is characterised by the contemporary understanding of small states' features and limitations in international affairs. Nevertheless, the effect of legal and conceptual aspects on small states' prospects, directing them towards systemic irrelevance, low influence and capabilities, and vulnerability against power asymmetry, is outweighed by the practical perspective that Lithuania and Estonia have taken during their two-year terms in the UNSC.

The research outlines that the objective boundaries of the eventual performance of small states in the UNSC, set by legal and conceptual aspects, can be supplemented with effective and visible work in this institution. Nevertheless, the theoretical aspects can be outweighed by the practical perspective only under circumstances where there is 
Gunda Reire. Small States in the United Nations Security Council:

Legal and Conceptual Aspects versus Practical Perspective

lack of systemic challengers, lack of triggers negatively impacting the security of particularly small states, and overlapping of the international security agenda with the field of expertise of a particular UNSC non-permanent member during its term of membership.

\section{Conceptual Aspects of Small States' International Capacity and Capabilities}

In academia, there is no strict consensus about a precise definition of small states and parameters that can be applied to categorise small states as a separate group. However, that does not mean that such term is too vague to operate with. Just on the contrary the research on small states can be qualified as extensive, and debates about the content of the term are ongoing. The contemporary concept of small states is complex and dynamic, and it has been expanded beyond the pessimistic boundaries of small states' victimhood, extreme vulnerability, smallness, helplessness and systemic irrelevance.

General statistical measurements of small states encompass the size of the territory, population size, gross domestic product, and military expenditure, thus referring to a separate group of states that are not great powers and that lack power in quantitative sense (Wivel et al., 2016). This aspect can be complemented with the characteristic of limited capacity of political, economic, and administrative systems (Baldacchino and Wivel, 2020). It should be noted that such specific parameters are more characteristic of the concept of small states in the $19^{\text {th }}-20^{\text {th }}$ centuries whereas nowadays the quantitative aspect of the definition and conceptualization of small states is enhanced by more sophisticated elements of behaviour and capacity regarding dealing with systemic challenges.

General behavioural patterns of small states after the Cold War cover the tendency to adapt to the environment instead of shaping it and seeing the potential of influence in membership of international organisations (Archer and Nugent, 2002; Baldacchino and Wivel, 2020, Panke, 2010; Steinmetz and Wivel, 2010; Wivel et al., 2016). International institutions play the role in platforms of influence and institutional shelter, which are able not only to provide additional dimension to small states' security within the international system, but even replace the state-protector relationships (Bailes \& Thorhallson, 2013; Wivel et al., 2016). Growth of international institutions also serves as an influencing factor for an increasing number of working platforms and areas of influence and visibility of small states, simultaneously putting under pressure one of the most important quantitative features of small states - limited and thinly stretched diplomatic and administrative resources (Baldacchino \& Wivel, 2020).

Classic theory of relative capabilities underlines four characteristics of (lack of) power: fewer capabilities to preserve autonomy in the context of power politics; narrow range of possible action; scarce options for defining the international agenda and rules that pertain to it; small stake in the international system and low capabilities to act for its sake (Waltz, 1979). These features of the concept of small states emphasise the thinking of the neorealist or structural realist school, and it is often criticised because of the excessive focus on military security (Wivel et al., 2016), leaving out of attention, for example, 
Gunda Reire. Small States in the United Nations Security Council:

Legal and Conceptual Aspects versus Practical Perspective

such contemporary concepts as human security, economic security, cybersecurity, and environmental security. Nevertheless, in the context of this research, which analyses the prospects of small states in the UNSC, the structural realists' approach is applicable, since the primary responsibility of the UNSC is international peace and security and its composition and decision-making mechanisms reflect realities of the power politics after World War II. Although the human security aspect has become more visible in the UNSC work after the Cold War (Dedring, 2008), it is nevertheless framed in the context of interstate and intra-state conflict.

International challenges that small states face in the $21^{\text {st }}$ century are rarely systemic ones. They are rather related to small states as a weaker part in asymmetric relations (Baldacchino and Wivel, 2020; Wivel et al., 2016), geopolitical situation in the region, challenges and opportunities that are grounded in the historical background and have a specific spacio-temporal context (Wivel et al., 2016; Maass, 2020). Therefore, for analytical and comparative purposes, the quantitative aspect is not sufficient - in order to group small states to uncover their relative possibilities and limitations, the common geopolitical, historical and geographical context is essential. The existing theoretical debate about the division line between microstates, small states, middle powers and great powers is not relevant within this research, as Latvia, Lithuania and Estonia with their parameters do not challenge any of the cut-off lines and for academic purposes are clearly definable as small states.

Therefore, instead of looking for universal parameters of small states, this article focuses on features of small states that are relational, qualitative and revealed in action. These are: (1) systemic dependence; (2) limited (financial, human and administrative) resources; (3) low capabilities for agenda-setting systemically; (4) vulnerability against power asymmetry; (5) a narrow range of action; (6) geopolitical location and historical context; and (7) international institutions as a vehicle of international influence. These features have both analytical and political dimensions, and they allow for distinguishing areas and aspects of the UNSC work where small states' influence is low, and where the scope of visible and effective activities is relatively wide, but options and solutions are available.

\section{Institutional and Procedural Aspects of Small States' UNSC Membership}

Legal aspects of small states' capability, influence, and effective and visible work within the UNSC can be grouped into institutional and procedural containers, and they are outlined in the UN Charter, two UN General Assembly (UNGA) resolutions - UNGA resolution 1991-XVIII and UNGA Resolution 2847 (XXVI), the Rules of Procedure of the General Assembly and the Provisional rules of procedure of the Security Council.

\subsection{Institutional Aspects of Small States' UNSC Membership}

From the institutional perspective of small states' activity in the UNSC, Article 23, para. 1 of the Charter of the United Nations provides the most important parameter, 
Gunda Reire. Small States in the United Nations Security Council:

Legal and Conceptual Aspects versus Practical Perspective

which says that UNSC consists of five permanent members (the five great powers the winners of World War II - with permanent membership) and ten non-permanent members, therefore providing only one possible UNSC membership option for small states:

"The Security Council shall consist of fifteen Members of the United Nations. The Republic of China, France, the Union of Soviet Socialist Republics [now the Russian Federation, successor of the seat - auth.], the United Kingdom of Great Britain and Northern Ireland, and the United States of America shall be permanent members of the Security Council. The General Assembly shall elect ten other Members of the United Nations to be non-permanent members of the Security Council [...." (United Nations Charter)

The Charter of the United Nations - Article 23, para. 2 - also regulates the term of non-permanent membership, and it is very short - two years - and does not allow a possibility that a non-permanent member de facto works permanently or a longer term than two years, because immediate re-election is excluded:

"The non-permanent members of the Security Council shall be elected for a term of two years. [..] A retiring member shall not be eligible for immediate re-election." (United Nations Charter)

This clearly highlights the power and influence disproportionality between permanent and non-permanent members. The Charter of the United Nations, Article 23 also provides criteria that UN General Assembly (UNGA) should consider when electing members of the UNSC, one of them being equitable geographical distribution:

"The General Assembly shall elect ten other Members of the United Nations to be non-permanent members of the Security Council, due regard being specially paid [..]

to equitable geographical distribution." (United Nations Charter)

However, the Charter does not define any parameters or characteristics for the mentioned equitable geographical distribution of the UNSC non-permanent seats. For purposes of UNSC election, the pattern is set out in UNGA resolution 1991-XVIII (let. A):

"[..] (a) Five from African and Asian States;

(b) One from Eastern European States;

(c) Two from Latin American States;

(d) Two from Western European and other States." (U.N. Doc. A/RES/1991(XVIII))

It is important that the regulation set forth by UNGA resolution 1991-XVIII cannot be considered as an amendment to the Charter, it has never been subject to ratification under Article 108 of the Charter, and this UNGA decision does not have a binding character, though it nevertheless has a legal value and has a typical legal effect of the recommendations of UN organs (Conforti, 2005), and it is regarded as UN customary law. 
Gunda Reire. Small States in the United Nations Security Council:

Legal and Conceptual Aspects versus Practical Perspective

The UNSC candidates usually announce their intention to run many years ahead before the election by informing their regional group and identifying the two-year term for which it intends to become a non-permanent member. This tradition not only supports good communication environment, but also clearly indicates whether UNSC elections will be contested within the regional group (Reire, 2021). The Baltic Countries belong to the Eastern European Group in the UN (United Nations. Regional...). Lithuania was unanimously elected as a UNSC non-permanent member running unopposed in the 2013 elections. Estonia participated in a contested election against Romania in 2019 and won with 132 UNGA votes (Security Council Report). Latvia will participate in a contested election in 2025 since Montenegro has also announced its interest for the same seat in 2025 (Statement by H.E. ..., 2013).

Institutionally, additional feature of membership and international visibility, which may be regarded as having a potential for power and influence, is outlined in the Provisional Rules of Procedure of the Security Council, Rule 18, and speaks about the UNSC Presidency:

"The presidency of the Security Council shall be held in turn by the members of the Security Council in the English alphabetical order of their names. Each President shall hold office for one calendar month." (U.N. Doc. S/96/Rev.7)

Although the role of the President of the UNSC, according to the Provisional Rules of Procedure of the Security Council, can be viewed strictly as narrow and in the light of chairmanship of the meeting (Rule 19) and approving the UNSC provisional agenda drawn up by the UN Secretary-General (Rule 7) and it does not involve the power to set the agenda, it can be viewed as a granted opportunity in hands of every non-permanent member.

Therefore, institutionally, the only option of UNSC membership for small states is the non-permanent one, with a short term of two years and on strictly rotational basis, but with a granted status of terminated UNSC Presidency.

\subsection{Procedural Aspects of Small States' UNSC Membership}

The main procedural aspects of small states' UNSC membership are covered by the UN Charter, and the most significant rule concerns the so-called Yalta formula (Conforti, 2005) which demands unconditional agreement of permanent members in substantive questions and confirms the veto power of the permanent members of the UNSC. This rule is outlined in Article 27, para. 3:

"Decisions of the Security Council on all other matters shall be made by an affirmative vote of nine members including the concurring votes of the permanent members [..]. (United Nations Charter)

The veto power has been a subject of academic scrutiny for decades since the very first years of the UN. It is generally acknowledged in both academic and political circles 
Gunda Reire. Small States in the United Nations Security Council:

Legal and Conceptual Aspects versus Practical Perspective

as a non-democratic and exclusive power and instrument, paralysing the UNSC activity and weakening the UNSC capability to ensure its main function - maintenance of international peace and security - effectively.

Moreover, theoretically and in praxis, there exists the problem of the double veto or the option to exercise the veto power outlined in Article 27, para. 3 regarding the preliminary question, when the UNSC cannot decide whether the question brought before the UNSC concerns the procedure or not (Conforti, 2005; Liang, 1949; Rudzinski, 1951), or, in other words - whether para. 2 or para. 3 of Article 23 of the Charter of the United Nations is applicable. Neither the Charter, nor the UNSC praxis provide clear solutions of this problem, but the practice (although there have been few cases) tends more to be in favour of the right of veto, but none of the UN organs has the absolute and sovereign power to interpret the Charter (Conforti, 2005).

The second significant procedural aspect influencing the activity of small states in the UNSC regards the power to define the agenda of the UNSC and therefore - of the global peace and security situation and solutions in general. This aspect is especially important from the point of view of practical policy solutions, since candidate countries often mention it as an argument for the candidacy and the possible gain and positive result from the eventual two-year UNSC membership. The most important conclusion from the procedural point of view here is that convocation of the UNSC must be observed separately from the UNSC's actual performance (Conforti, 2005).

On the one hand, the Charter of the United Nations, Article 35, para. 1 grants any member state the power to seize the UNSC, which theoretically indicates the power to influence the UNSC agenda:

"Any Member of the United Nations may bring any dispute, or any situation of the nature referred to in Article 34, to the attention of the Security Council or of the General Assembly." (United Nations Charter)

In addition, when the member state(s), the UNGA or the Secretary-General act on the basis of respective Charter provisions, the UNSC is obliged to meet, as it is regulated by the Provisional Rules of Procedure of the Security Council, Rule 2 and 3:

"The President shall call a meeting of the Security Council at the request of any member of the Security Council." (U.N. Doc. S/96/Rev.7)

"The President shall call a meeting of the Security Council if a dispute or situation is brought to the attention of the Security Council under Article 35 or under Article 11 (3) of the Charter, or if the General Assembly makes recommendations or refers any question to the Security Council under Article 11 (2), or if the SecretaryGeneral brings to the attention of the Security Council any matter under Article 99." (U.N. Doc. S/96/Rev.7)

On the other hand, the mentioned regulation, which emphasises the possibility of bringing the issue to the attention of the UNSC by any UN member state and UNSC 
Gunda Reire. Small States in the United Nations Security Council:

Legal and Conceptual Aspects versus Practical Perspective

member, concerns only convocation of the UNSC. Namely, Rule 3 of the UNSC procedure speaks about the situation, where the UNSC must decide whether the conditions of the situation (real danger to peace) are sufficient to exercise its functions, and, if the UNSC decides that conditions are insufficient, the issue will not be included in the actual agenda (Conforti, 2005). In its turn, Rule 2 of the UNSC procedure is relevant only in situations when the UNSC is already considering particular question, or in other words - is already included in the organ's agenda.

Therefore, the procedural aspect further deepens the power projection gap between permanent and non-permanent UNSC members, outlined by the institutional aspect. The main procedural element restraining the small states' performance in the UNSC is the veto power, since it does not allow making a decision without unanimity of permanent members. Moreover, although in the political discourse there exists the thesis that non-permanent membership gives an opportunity to influence the global peace and security agenda, legal provisions clearly show that UNSC agenda cannot be substantially influenced without the consent of the permanent members.

Legal and conceptual aspects of small states and particularly - the Baltic States membership in the UNSC show a narrow and constrained field of play and seemingly point in the direction towards a pessimistic view of small states' minuteness, helplessness and systemic irrelevance. Therefore, the theoretical prospects for small states of capability, influence and effective and visible work within the UNSC can be considered as minor (Table 1).

Table 1. Legal and Conceptual Aspects of the Baltic States' Membership in the UNSC: Summary

\begin{tabular}{|c|c|c|}
\hline \multicolumn{2}{|c|}{ Legal aspects } & \multirow{2}{*}{ Conceptual aspects } \\
\hline Institutional & Procedural & \\
\hline \multirow{2}{*}{$\begin{array}{l}\text { The only option: non-permanent } \\
\text { membership. }\end{array}$} & \multirow{3}{*}{$\begin{array}{l}\text { Decisions on substantive } \\
\text { matters cannot be taken without } \\
\text { unanimity of the permanent } \\
\text { members (veto). }\end{array}$} & Systemic dependence. \\
\hline & & \multirow{2}{*}{$\begin{array}{l}\text { Limited (financial, human and } \\
\text { administrative) resources. }\end{array}$} \\
\hline Membership is strictly rotational. & & \\
\hline $\begin{array}{l}\text { Membership has a short term of } \\
\text { two years. }\end{array}$ & Double-veto problem. & $\begin{array}{l}\text { Low capabilities of agenda- } \\
\text { setting systemically. }\end{array}$ \\
\hline $\begin{array}{l}\text { Membership grants a status of } \\
\text { terminated UNSC Presidency. }\end{array}$ & $\begin{array}{l}\text { Wide opportunities to bring } \\
\text { the issue to the attention to }\end{array}$ & $\begin{array}{l}\text { Vulnerability against power } \\
\text { asymmetry. }\end{array}$ \\
\hline \multirow{3}{*}{$\begin{array}{l}\text { The Baltic Countries candidate } \\
\text { for the seat from the Eastern } \\
\text { European Group. }\end{array}$} & council. & Narrow range of action. \\
\hline & \multirow{2}{*}{$\begin{array}{l}\text { Narrow opportunities to bring } \\
\text { any matter to the actual UNSC } \\
\text { agenda without the consent of } \\
\text { the permanent members. }\end{array}$} & $\begin{array}{l}\text { Geopolitical location and } \\
\text { historical context play a } \\
\text { prominent role. }\end{array}$ \\
\hline & & $\begin{array}{l}\text { International institutions } \\
\text { are a vehicle of international } \\
\text { influence. }\end{array}$ \\
\hline
\end{tabular}


Gunda Reire. Small States in the United Nations Security Council:

Legal and Conceptual Aspects versus Practical Perspective

\section{Practical Perspective: Lithuania's and Estonia's Work in the UNSC}

In this chapter of the article, legal and conceptual aspects are compared with the actual performance of Lithuania (the UNSC term 2014-2015) and Estonia (the UNSC term 2020-2021) during their respective UNSC membership terms in order to determine whether theoretical aspects can be outweighed and compensated by the practical perspective.

\subsection{International Institutions as a Tool for Raising International Status}

The Baltic States' membership and candidacy for the UNSC emphasises the conceptual aspect of international institutions as a necessary tool for securing small states' positions in the world. The UNSC membership generally can be seen in the light of enhancing international standing and relevance, underscoring the international prestige, advancing a national position, and gaining broader foreign policy objectives (Malone, 2000). It is worth mentioning that while all UNSC non-permanent members have similar expectations towards networking during their term, small states in particular have lower expectations in gaining influence but higher expectations on raising their international status (Raik, 2021).

The aims and conclusions of Baltic States about their UNSC candidacy or membership confirm this conceptual aspect. Estonia has declared that its election as a non-permanent member of the UNSC demonstrates the maturity of Estonian diplomacy, raises Estonia's profile and visibility across the world and its ability to bolster its security and readiness to engage in solving global problems and managing conflicts (Estonia in the..., 2020). Lithuania, by emphasising the focus of UN values - its commitment to protect human rights, promote democracy and enhance cooperation among sovereign and equal states, based upon primacy of international law - has concluded that the two-year diplomatic work on the UNSC "have made us stronger" (Ministry of the..., 2016).

\subsection{Candidacy, Term, and Regional Rotation}

International ambition is seen as one of the success factors in effectively fulfilling the short two-year term at the UNSC, considering that the next term will most likely not be possible in a foreseeable future because of limited resources and the fact that 6 of 23 UN Eastern European Group members still have not been members of the UNSC (Countries Never Elected...). It must also be noted that Russia, which represents the same regional group, is a permanent member of the UNSC, but two Eastern European Group members - Ukraine and Belarus - have the specific status of UN founding members, although they could not be considered international subjects in 1945 (Conforti, 2005), and have been UNSC non-permanent already during the Cold War period (Countries 
Gunda Reire. Small States in the United Nations Security Council:

Legal and Conceptual Aspects versus Practical Perspective

Elected Members, 2021). The international ambition in combination with restricted working period as a focal point of the membership has been underlined by Sven Jürgenson, the Permanent Representative of Estonia to the UN. He emphasises that the role of small states in the UNSC depends very much on their level of ambition, and Estonia was aware of the practical implications of the shortness of its two-year term, which is available "once in a generation" and can be fulfilled with the help of being as ambitious and as "active as possible" (Raik, 2021).

A mechanism that supports newly elected UNSC members and is especially important for the Baltic States because of their lack of previous UNSC experience, is a regulation concerning the Working Methods of the UNSC, Article 140, which aims to familiarise the newly elected members with the work of the UNSC and its subsidiary bodies:

\footnotetext{
"The Security Council invites the newly elected members of the Council to observe all meetings of the Council and its subsidiary bodies and the informal consultations of the whole for a period of three months, as from 1 October immediately preceding their term of membership. The Council also invites the Secretariat to provide all relevant communications of the Council to the newly elected members during the abovementioned period" (Handbook on the..., 2021)
}

From the point of view of the limited resources available to small states, the principle of regional rotation in a UNSC election cannot be evaluated in a-sided manner. On the one hand, this principle ensures higher probability and higher possibilities for small states to be elected to the UNSC. On the other hand, the contested elections drain the limited resources of small states even more. Lithuania ran unopposed in its election as the UNSC non-permanent member in 2013 elections, whereas Estonia participated in a contested election against Romania in 2019 and won by gaining 132 UNGA votes (Security Council Report, 2021).

\subsection{Geopolitical Location and Historical Context}

International standing and relevance of small states is highly dependent on their geopolitical location, geopolitical situation, and historical context.

First, Lithuania's and Estonia's UNSC membership and Latvia's candidacy for the non-permanent seat reflect both the historic and geopolitical aspects, and the process of growth of the international potential of these three countries. During the Cold War under the Soviet occupation, the Baltic States had neither the possibility to work in the UNSC nor options to gain direct experience in multilateral relations. This experience of integration into international system had to be achieved in the years after the collapse of the Soviet bloc. Therefore, Lithuania started its term as a UNSC member 23 years after regaining independence, Estonia - 29 years, and Latvia in the case of a positive UNGA vote will have a non-permanent UNSC seat for the first time 35 years after regaining independence in 1991. Of all European Union member states, Latvia and Cyprus are the last ones without the UNSC experience (Countries Never Elected...). 
Gunda Reire. Small States in the United Nations Security Council:

Legal and Conceptual Aspects versus Practical Perspective

Second, cases of Lithuania's and Estonia's membership show that their work in the UNSC gives an opportunity to highlight issues relevant for the security of the Baltic region and gives broader meaning of shared geopolitical and historical patterns with neighbouring countries. Lithuania has acknowledged that standing up in defence of the international community's most fundamental principles: sovereignty, territorial integrity, and freedom in the context of Crimea's illegal annexation by Russia was Lithuania's primary task and duty on the UNSC and shaped its role in this prominent institution (Ministry of the..., 2016). The focus on security issues of the region was further ensured by Estonia by keeping the issues of Belarus, Ukraine, and Georgia high on the agenda. Among all activities it is worth highlighting two UNSC formal meetings (Estonia in the..., 2020) and two informal meetings in 2020 (Human Rights in..., 2020 and 2021 (The Situation in..., 2021) on situation in Belarus. Estonia's example also underlines effective use of the Arria formula, which is a relatively recent praxis that involves inviting participants to informal deliberations within a flexible procedural framework ("ArriaFormula" meetings..., 2002).

Therefore, the conceptual aspect of geopolitical location and historical context in the praxis of small states' UNSC membership can be a facilitating factor in terms of agenda setting, maintaining regional security and shaping a particular country's foreign policy profile. The conceptual aspect of geopolitical and historical context can have a positive potential of effective UNSC membership in cases where there is a stable security situation, because protection from aggression, strong international law and open international economy shape the international environment in a way that is highly supportive for small states (Maass, 2020). Nevertheless, this conceptual aspect has a predominantly negative potential in asymmetric relations and an unstable security environment.

\subsection{Presidency and Agenda-setting}

The UNSC Presidency is a formal duty, which nevertheless can be regarded as a granted opportunity for a UNSC non-permanent member to become visible and to use an international institution as a tool for shaping its international reputation and profile. Bearing in mind that the UN serves as a platform for influence for those states which are willing and able to focus and prioritise their material and human resources and work through regional groups (Panke and Gurol, 2020), the effective use of this opportunity, however, depends on member states diplomatic professionalism.

Both Lithuania and Estonia have had two one-month UNSC Presidencies. During its first Presidency in February 2014, Lithuania's focus was relatively broad on the issues of the rule of law, protection of civilians, and cooperation between the UN and regional organisations (Ministry of the..., 2016). However, during last days of this Presidency the conflict in Ukraine was for the first time raised in the UNSC, and the first emergency meeting on the situation in Ukraine was held (U.N. Meeting... (2014). Lithuania acknowledges that the factor of Ukraine's predicament at the time had a strong effect 
Gunda Reire. Small States in the United Nations Security Council:

Legal and Conceptual Aspects versus Practical Perspective

on the shaping of its role in the UNSC at large (Ministry of the..., 2016). It is a clear example of overlapping of the international agenda with a non-permanent member's expertise and security interests that has enhanced its potential to fulfil its responsibilities as part of the UNSC membership while boosting its international profile and increasing its visibility.

Estonia's profile of the UNSC membership encompasses international law, fundamental values, cybersecurity and working methods of the UNSC (Estonia in the..., 2020). Both Estonia's Presidencies in May 2020 and June 2021 took place in the context of Covid-19 pandemic. During its first Presidency, the UNSC worked remotely and for the first time in history, the UNSC meetings were held in an online format, which overlapped with Estonia's UN profile (digital and cyber-security agenda; working methods of the Security Council). International visibility was also enhanced by the $75^{\text {th }}$ anniversary of the end of the World War II, which was celebrated with the help of a high-level Arria-formula meeting, chaired by Urmas Reinsalu, the Minister of Foreign Affairs of the Republic of Estonia, live-streamed globally (Signature Event on..., 2020b), and powered by Hybridity, an Estonian virtual event platform.

Although, theoretically, agenda-setting possibilities in the UNSC for the small states are limited and their capabilities of agenda-setting systemically can be evaluated as low, a combination of an international agenda dovetailing with national expertise, clear priorities, and creative, flexible use of available instruments and adaption to the international environment has a higher practical potential than the theory provides and predicts.

\subsection{Limited Resources and Narrow Range of Action}

Conceptually, the aspects of small states' limited financial, diplomatic and administrative resources as well the narrow range of possible action, which directly results from the lack of resources, are objective. They constitute objective boundaries and restrictions in the UNSC membership, which have to be taken into account during the election campaign and the actual membership.

Lithuania's and Estonia's cases show that the solution to this situation is profiling and specialisation. Lithuania's work during its UNSC membership was more focused on general problematics of international security and systemic stability, and this supports the conceptual aspects of systemic dependence and vulnerability against power asymmetry. Lithuania's work became more profiled on Ukraine after Russia's aggression (Ministry of the..., 2016) and became the most prominent feature of Lithuania's membership. It outlines the significance of a small state's ability to react to events of international agenda within the profile of its foreign policy.

Estonia's UNSC priorities are very well defined and precise. These are: international law, rules-based world order, new threats (climate change and cyber security), and working methods of the Council (Raik, 2021), and Estonia is also the co-penholder with Norway on the theme of Afghanistan, which was a major topic on the UNSC agenda already before the withdrawal of the US forces in 2021 (Estonia in the..., 2020). 
Gunda Reire. Small States in the United Nations Security Council:

Legal and Conceptual Aspects versus Practical Perspective

Estonia's emphasis on upholding international law and a rules-based order not only supports the UN agenda at large but is even more important for Estonia as a small state that benefits from international stability and order. Cyber security falls into the category of Estonia's nation branding profile, while keeping the UNSC agenda corresponding to the digital age. Estonia succeeded in bringing a new aspect into the UNSC work: the cybersecurity agenda. As part of its presidency, for the first time in the UNSC history, Estonia organised a virtual meeting in a format of Arria-formula, focused on stability in cyberspace, cyber norms, and international law (Signature event of..., 2020a), thus contributing both to global and national security agenda.

The aspects of limited resources and narrow range of action emphasise the need for prioritising work of small states at three different levels: global (systemic) level, national foreign policy level and institutional (UN) level. This conclusion underlines the need of small states to minimise the systemic dependence and vulnerability against power asymmetry by contributing to the stability of the international system and the rule of law, because the role of small states is dependent on system-relevant factors and forces beyond the immediate control of small states (Maass, 2020). It also shows the necessity of having a clear national foreign policy brand and priorities to achieve high international visibility.

\section{Conclusions}

The article outlines that the legal and conceptual boundaries for small states' capability, influence, and effective and visible work within the UNSC are objective, but they can be outweighed by the practical perspective, as it is outlined in the case studies of Lithuania's and Estonia's membership.

This can be done by: (1) setting forth clear foreign policy priorities and UNSC membership priorities at three levels: systemic (strengthening of the stability of international system and international law), national (profiling of foreign policy in the context of lack of resources), and institutional (strengthening the UN as a shelter against external shocks); (2) using and expanding actively and creatively all possible UNSC work formats, including informal ones; (3) profiling and selectively engaging in those international agenda issues that dominate the UNSC agenda and fall into the purview of the particular state's expertise or geographical proximity. These conclusions and outlined strategies are important for Latvia's candidacy and eventual UNSC membership.

Nevertheless, legal and conceptual constraints of small states' international influence can be minimised only in a supportive international system: where small states' physical security and territorial integrity are not threatened, the rule of law protects from aggression, and systemic challengers and triggers to the security of particular small states are low. 
Gunda Reire. Small States in the United Nations Security Council:

Legal and Conceptual Aspects versus Practical Perspective

\section{Bibliography}

1. Archer, C., Nugent, N. (2002). Introduction: Small States and the European Union. Current Politics and Economics of Europe, 11(1), 1-10.

2. "Arria-Formula" meetings of Security Council members. Background Note. Informal Non-paper XVII, 25 October 2002. (2021). Handbook on the Working Methods of the Security Council. https:// www.un.org/securitycouncil/sites/www.un.org.securitycouncil/files/handbook_on_the_working_methods_of_the_security_council.pdf.

3. Bailes, A. J. K., Thorhallsson, B. (2013). Instrumentalizing the European Union in Small State Strategies. Journal of European Integration, 35(2), 99-115.

4. Baldacchino, G. Wivel, A. (2020). Small states: concepts and theories. In Handbook on the Politics of Small States. Baldacchino, G. Wivel, A. (eds.). Edward Elgar Publishing, pp.2-19.

5. Conforti, B. The Law and Practice of the United Nations. Third revised edition. Leiden / Bonston: Martinus Nijhoff Publishers, 2005.

6. Countries Elected Members. United Nations Security Council. https://www.un.org/securitycouncil/content/countries-elected-members.

7. Countries Never Elected Members of the Security Council. United Nations Security Council. https://www.un.org/securitycouncil/content/countries-never-elected-members-security-council.

8. Dedring, J. (2008). Human Security and the UN Security Council. Globalization and Environmental Challenges. Hexagon Series on Human and Environmental Security and Peace, vol 3. Brauch H.G. et al. (eds). Springer, Berlin, Heidelberg. https://doi.org/10.1007/978-3-54075977-5_46.

9. Estonia in the UN Security Council. (2020). Ministry of Foreign Affairs of the Republic of Estonia. https://vm.ee/en/activities-objectives/estonia-united-nations/estonia-un-security-council.

10. Handbook on the Working Methods of the Security Council. (2021). United Nations Security Council. https:/www.un.org/securitycouncil/sites/www.un.org.securitycouncil/files/handbook_on_the_working_methods_of_the_security_council.pdf.

11. Human Rights in Belarus: UN Security Council Arria meeting. (2020). Ministry of Foreign Affairs of the Republic of Lithuania (estonianmfa), YouTube. https://www.youtube.com/ watch?v=F4mQE8taqJA.

12. Liang, Y. (1949). The So-Called “Double Veto”. The American Journal of International Law, 43(1), 134-144. https://doi.org/10.2307/2193146.

13. Ministry of Foreign Affairs of the Republic of Lithuania. (2016). Lithuania at the United Nations Security Council 2014-2015. Vilnius: Eugrimas.

14. Maass, M. (2020). Small states: surviving, perishing and proliferating through history. In Handbook on the Politics of Small States. Baldacchino, G. Wivel, A. (eds.). Edward Elgar Publishing, 20-37.

15. Malone, D. (2000). Eyes on the Prize: The Quest for Nonpermanent Seats on the UN Security Council. Global Governance. Vol. 6, no. 1 (2000), 3-23.

16. Panke, D. (2010). Small States in the European Union. Aldershot: Ashgate.

17. Raik, K. (2021). UN Security Council in Times of Great Power Rivalry: How Can Small States Make a Difference? The International Centre for Defence and Security (ICDS). https://icds.ee/ en/24-march-un-security-council-in-times-of-great-power-rivalry-how-can-small-states-makea-difference/. 
Gunda Reire. Small States in the United Nations Security Council:

Legal and Conceptual Aspects versus Practical Perspective

18. Reire, G. (2021). Attīstības palīdzība kā ekonomisks faktors ANO Drošības padomes vēlēšanās: Mācība Latvijai [Development aid as an economic factor in the United Nations Security Council election: Lessons for Latvia]. LZA Vēstis, A daḷa, 2021.g. 3. numurs, 13-28.

19. Rudzinski, A. W. (1951). The So-Called Double Veto. The American Journal of International Law, 45(3), 443-461. https://doi.org/10.2307/2194543.

20. Rules of Procedure of the General Assembly. United Nations. https:/www.un.org/en/ga/about/ ropga/.

21. Security Council Elections 2021. Security Council Report. https://www.securitycouncilreport. org/atf/cf/\%7B65BFCF9B-6D27-4E9C-8CD3-CF6E4FF96FF9\%7D/unsc_elections_2021.pdf.

22. Signature Event of Estonia's UNSC Presidency: Cyber Stability, Conflict Prevention and Capacity Building. (2020a). Ministry of Foreign Affairs of the Republic of Estonia. https://vm.ee/en/activities-objectives/estonia-united-nations/signature-event-estonias-unsc-presidency-cyber.

23. Signature Event in the UN: High-Level Meeting on the 75th Anniversary of the End of WWII in Europe (2020b). Ministry of Foreign Affairs of the Republic of Lithuania (estonianmfa), YouTube. https://www.youtube.com/watch?v=Ohljz-a1fZE.

24. Steinmetz, R., Wivel, A. (2010). Introduction. In Small states in Europe: Challenges and Opportunities. Steinmetz, R., Wivel, A. (eds.) Aldershot: Ashgate, 1-14.

25. The Situation in Belarus: UN Security Council Arria meeting. (2021). Ministry of Foreign Affairs of the Republic of Lithuania (estonianmfa), YouTube. https://www.youtube.com/ watch? $=$ nBSw08gJ4J8.

26. U.N. Doc. A/RES/1991(XVIII). https://undocs.org/A/RES/1991(XVIII).

27. U.N. Doc. S/96/Rev.7. Provisional rules of procedure of the Security Council. https://undocs. org/en/S/96/Rev.7.

28. United Nations Charter. United Nations. https://www.un.org/en/about-us/un-charter.

29. United Nations. Regional groups of Member States. United Nations. https://www.un.org/dgacm/ en/content/regional-groups.

30. U.N. Security Council Meeting on Ukraine. (2014). C-Span. https://www.C-span.org/ video/?318084-1/russian-intervention-ukraine.

31. Statement by H.E. Milo Djukanovic, Prime Minister of Montenegro, at the General Debate of the $68^{\text {th }}$ Session of the United Nations General Assembly. (2013). United Nations. https:// gadebate.un.org/sites/default/files/gastatements/68/ME_en.pdf.

32. Waltz, K. N. (1979). Theory of International Politics. New York: McGraw-Hill,194-195.

33. Wivel, A., Bailes, A. J. K., Archer, C. (2016). Small states, survival and strategy. In Small States and International Security. Europe and beyond. Archer, C., Bailes, A. J. K., Wivel, A. (eds). Routledge, 3-25. 